UDK 378.147

DOI: $10.36550 / 2415-7988-2020-1-188-59-63$

\author{
HABELKO Olena Mykolayivna - \\ Ph.D., Associate Professor \\ Department of Linguodidactics and Foreign Languages \\ Volodymyr Vynnychenko Central Ukrainian State Pedagogical University \\ ORCID:https://orcid.org/0000-0003-3769-3616 \\ e-mail: Lena_Gabelko@i.ua
}

\title{
TO THE PROBLEM OF HUMANIZATION IN THE PEDAGOGICAL PROCESS
}

Formation and justification of the relevance of the problem. Nowadays, societies tend to be structured globally by political, economic and social changes in the EU and worldwide. The challenge is to provide a space in which all citizens can identify themselves and interact with each other. Thus, becoming active citizens is a guarantee for the development of social democracy.

A humanizing education relies on the pedagogy of educators who are navigating, coexisting, or adhering to the sociopolitical practices of their schools. Constructing belief and practices around a humanizing education focuses on the current reality, culture, and lived experiences of the learner [11, p. 1].

Analysis of resent research and publications. Historically, influential educators, social activists, and critical pedagogues such as Freire (1970), Kincheloe and McLaren (2000), Giroux (2001), Darder (2002) have challenged educational conditions and monolithic practices (e.g., standardized curriculum) worldwide. For over a century, these educational activists have been placed in exile, experienced political turmoil and received criticism from the mainstream antidemocratic system. Over the years of challenge and unrest, the emancipatory efforts of these leaders and their vision for education surfaced as some of the most influential philosophies in pedagogical and curricular studies.

Paulo Freire, often cited as the father of critical pedagogy, remained true to his vision for humanization up until his death in 1997 (Darder, Baltodano, \& Torres, 2009). Freire (1970) attended to this vision as he wrote, «In order to achieve humanization, which presupposes the elimination of dehumanizing oppression, it is absolutely necessary to surmount the limitsituations in which men (and women) are reduced to things» $[4$, p. 93$]$.

Recent research studies have identified pedagogical approaches and practices that lead to a humanizing education (Bartolomé, 1994; Darder \& Torres, 2004; Giroux, 2011; Kirylo, Thirumurthy, Smith, \& McLaren, 2010; Salazar, 2013; Westerman, 2005). Lilia Bartolomé (1994) identified two approaches in her emphasis for creating a humanizing pedagogy «that respects and uses the reality, history, and perspectives of students as an integral part of educational practice» [1, p. 173].

A historically significant example of a humanizing pedagogical approach to literacy lies within Freire's early educational experiences in Brazil. In 1964, Freire launched the most successful national literacy campaign in Brazil's history (Darder, 1998). Scholars and practitioners who have transformed their pedagogical priorities to support literacy from a cultural and humanizing stance foundationally have supported literacy as a form of liberation (Westerman, 2005). Freire's belief in dialogic relationships, in which the experiences of both the student and the teacher create understanding through dialogue, formed the foundation for critical literacy practices. The role of the student in constructing a social reality is crucial to this foundation. The student becomes an active part of the curriculum by living within the educational process of socially constructing the world.

Literacy skills are no longer built upon the practice sentences in a prescribed reading program but, instead, are developed through dialogic sentences related to the reality and experiences of the student (Freire, 1970; Westerman, 2005).

As the extant literature has aimed to supply implications for a humanizing pedagogy rather than specific classroom practices, many of the philosophical exigencies, explained through the lens of these educational leaders, can be recontextualized into future educational settings [8].

A humanizing pedagogy is a process of becoming for students and teachers (Freire, 1970; Price \& Osborne, 2000; Roberts, 2000). Scholars of humanizing pedagogy insist that in schools, the process of becoming more fully human must be tethered to the needs of the whole person (Bell \& Schniedewind, 1989; Price $\&$ Osborne, 2000). For example, Price and Osborne (2000) describe humanizing pedagogy as «a pedagogy in which the whole person 
develops and they do so as their relationships with others evolve and enlarge» [9, p. 29]. Moreover, the authors note that the purpose of humanizing education is not only to transfer meaningful academic knowledge but to also promote the overall well-being of all students. Cammarota and Romero (2006) state that educators attend to students overall well-being when they connect with students on an emotional level by (a) providing reciprocal opportunities to share their lives, (b) demonstrating compassion for the dehumanizing experiences students of color encounter, and (c) situating learning in social issues that are relevant to the experiences of marginalized communities [3, p. 16-23].

The purpose of the article. The purpose of the article is to explore how teacher leaders influence pedagogical change toward a humanizing education. Learning environment, instructional design, and leadership practices are highlighted in this study as influences on the characteristics of a humanizing education.

The main material of the study. Humanism is a central component of Freire's worldview and is essential to understanding Freirean philosophy. Freire's philosophy is guided by the notion that humans are motivated by a need to reason and engage in the process of becoming. Freire's focus on humanism is centered on his curiosity in the cognitive capacity of humans to shape their experiences and achieve personal and collective selfactualization, thus developing their full humanity (Dale \& Hyslop-Margison, 2010; Schapiro, 2001).

Humanization is the process of becoming more fully human as social, historical, thinking, communicating, transformative, creative persons who participate in and with the world (Freire, 1972, 1984). To become more fully human, men and women must become conscious of their presence in the world as a way to individually and collectively re-envisage their social world (Dale \& Hyslop-Margison, 2010; Freire \& Betto, 1985; Schapiro, 2001). Humanization is the ontological vocation of human beings and, as such, is the practice of freedom in which the oppressed are liberated through consciousness of their subjugated positions and a desire for selfdetermination [4].

Humanization cannot be imposed on or imparted to the oppressed; but rather, it can only occur by engaging the oppressed in their liberation. As such, Freire (1970) proposes that the process of humanization fosters transformation and authentic liberation of the oppressed; thus, «to transform the world is to humanize it» $[5$, p. 70$]$.

Freire's use of the term pedagogy is a «complex philosophy, politics, and practice of education ... that demands of educators a clear ethical and political commitment to transforming oppressive social conditions» [10, p. 13-14]. According to Freirean ideals, all pedagogy is political and requires radical reconstruction of teaching and learning (Giroux, 1988); moreover, pedagogy must be meaningful and connected to social change by engaging students with the world so they can transform it (Giroux, 2010). As such, meaningful social change can be triggered by curricular resources that are tied to the needs of marginalized students and locally generated by teachers and communities in order to interrupt patterns of exclusion [11, p. 27].

In fact, Freirean pedagogy necessitates that educators reinvent his philosophy and pedagogy across contexts (Rodriguez \& Smith, 2011). Above all, Freire encourages educators to listen to their students and build on their knowledge and experiences in order to engage in contextualized, dynamic, and personalized educational approaches that further the goals of humanization and social transformation.

In Pedagogy of the Oppressed, Freire (1970) describes humanizing pedagogy as a revolutionary approach to instruction that «ceases to be an instrument by which teachers can manipulate students, but rather expresses the consciousness of the students themselves») [4, p.51]. Teachers who enact humanizing pedagogy engage in a quest for «mutual humanization» $[4$, p. 56] with their students, a process fostered through problem-posing education where students are coinvestigators in dialogue with their teachers. Analysis of the literature reveals the following five key tenets are requisite for the pursuit of one's full humanity through a humanizing pedagogy:

1. The full development of the person is essential for humanization.

2. To deny someone else's humanization is also to deny one's own.

3. The journey for humanization is an individual and collective endeavor toward critical consciousness.

4. Critical reflection and action can transform structures that impede our own and others' humanness, thus facilitating liberation for all.

5. Educators are responsible for promoting a more fully human world through their pedagogical principles and practices [11, p. 128].

Keet (2009) explored «humanizing» pedagogy and the dimensions of the human 
experience, stating, «A humanising pedagogy is a radical pedagogy, not a 'soft' one, and its humanising interest is linked to focusing on both structural and psycho-social dimensions of human suffering, and human liberation». A humanizing pedagogy is inclusive of the psychological and emotional dimensions of the human experience; thus, a humanizing pedagogy is intentionally focused on the affective domain (Bell \& Schniedewind, 1989) and requires that educators interact with students on an emotional level [3]. For instance, Cammarota and Romero (2006) suggest that students and teachers should share their perspectives about life and educators should express verbally and nonverbally their «faith in students' intellectual capacities and a respect for their concerns about the world» $[3$, p. 20].

A humanizing pedagogy correlates with caring literature in education and is inclusive of respect, trust, relations of reciprocity, active listening, mentoring, compassion, high expectations, and interest in students' overall well-being (Bartolomé, 1994; Cammarota \& Romero, 2006; Gay, 2010).

Ultimately, a humanizing pedagogy is rooted in the relationships between educators and students and, as such, respects the human, inter-personal side of teaching, and emphasizes the richness of the teacher-student relationships.

The individual and collective development of critical consciousness is paramount to the pursuit of humanization. According to Freire, in a humanizing pedagogy, «the method of instruction ceases to be an instrument by which teachers can manipulate the students, because it expresses the consciousness of the students themselves» [4, p. 51]. Students and teachers engage in a quest for mutual humanization [4, p. 56] through the development of critical consciousness.

Critical consciousness is the process of «learning to perceive social, political, and economic contradictions, and to take action against the oppressive elements of reality» [4, p. 17]. Moreover, critical consciousness is a process by which students learn to «think actively, and with intentionality and purpose» $[6$, p.6] about their own contributions and the contributions of society to the perpetuation of inequity, injustice, and oppression.

Bell and Schniedewind (1989) promote the notion that «consciousness of self can challenge unconscious oppressive or oppressing behaviors» [2, p. 211]. For instance, as educators develop consciousness of their own role in upholding inequitable structures, they come to act as oppositional intellectuals who engage critically with authority to develop pedagogical principles that link learning, social responsibility, and political agency (Giroux, 2010). Milner (2003) engages teacher candidates in critical self-consciousness through race reflective journaling.

Although critical self-consciousness is essential for a humanizing pedagogy, Freire insists that the pursuit of humanization can never be an isolated or individualistic endeavor. Accordingly, a humanizing pedagogy stems from relationships between educators and students and their collective and dialogic pursuit of humanization for all people (Huerta \& Brittain, 2010; Price \& Osborne, 2000; Roberts, 2000).

A humanizing pedagogy, thus, results from the individual and collective process of critical consciousness that is provoked through dialogue (Freire, 2000). Freire (1997) claims that dialogue requires an intense faith in humankind: faith in their power to make and remake, to create and recreate; faith in their vocation to be fully human - which is not the privilege of the elite, but the birthright of all humanity.

Scholars assert that by problematizing their collective experiences, they [teachers and students] employ the uniquely human capacity to be contemplative and have in-depth discussion to encourage reflection and eventual transformation. Problem-posing education engages students and educators in critical inquiry and creative transformation and promotes student engagement with issues of language, literacy, culture, ecology, democracy, and humanity (Bahruth, 2000; Schugurensky, 2011).

Freire suggests that developing critical consciousness and engaging in transformative dialogue requires teachers and students to become «subjects», rather than «objects», thereby creating reciprocity of teaching and learning. In Freire's words, «All educational practice requires the existence of 'subjects,' who while teaching, learn. And who in learning also teach» [4, p. 67]. As a result, teachers and students are essentially critical beings working together to co-construct knowledge (Shor \& Freire, 1987), and students can «feel they are knowledgeable Subjects that guide the educational process» [3, p. 20]. Jennings and Da Matta (2009) concur that through a humanizing pedagogy, students become subjects who actively make meaning of their own lives and the world around them, rather than objects who passively receive content knowledge from teachers.

Scholars propose that teachers who practice a humanizing pedagogy explicitly teach the 
school's codes and customs, and/or mainstream knowledge, to enable students to fully participate in the dominant culture. Delpit (2006) refers to school's codes and customs of the rules of the culture of those who have power as the culture of power; these include ways of talking, ways of writing, ways of dressing, and ways of interacting. Preparing students to participate successfully in the dominant culture equips students with the knowledge base and discourse styles privileged in society; however, scholars note that this process must be additive to students' existing cultural and linguistic resources (Bartolome, 1994; Huerta, 2011).

In summary, a humanizing pedagogy engages students in the following ways: making personal connections to learning, validating selves and others, focusing on what they can do and achieve with the cultural and linguistic resources they bring, expanding on their repertoire of possible selves (Fronquiz \& Salazar, 2004), strengthening cultural awareness and identity (Huerta, 2011; Nieto, 2002; Rumberger \& Larson, 1998; Salazar, 2008, 2010; ), intensifying consciousness of their own contribution and the contributions of society and schools to the hegemonic reproduction of oppressive structures (Allen \& Rossatto, 2009; Huerta \& Brittain, 2010), and instilling a belief in their own humanity.

In heeding Freire's call for a humanizing pedagogy, educational scholars have conducted research over the past four decades to illuminate the application of humanizing pedagogy in an educational setting. The principles and practices of humanizing pedagogy include the following: 1. The reality of the learner is crucial. 2. Critical consciousness is imperative for students and educators. 3. Students' sociocultural resources are valued and extended. 4. Content is meaningful and relevant to students' lives. 5. Students' prior knowledge is linked to new learning. 6. Trusting and caring relationships advance the pursuit of humanization. 7. Mainstream knowledge and discourse styles matter. 8. Students will achieve through their academic, intellectual, social abilities. 9. Student empowerment requires the use of learning strategies. 10. Challenging inequity in the educational system can promote transformation [11, p. 138].

Conclusions and prospects for further research of the direction. The main objectives of the humanistic oriented educational process in high school are humanistic orientation of the teaching process of all subjects in the curriculum; creating conditions suitable for the realization of an individual approach to the humanistic development of the future specialist's personality; establishing principles of cooperation and promoting the development of student activities in learning and research processes.

\section{СПИСОК ДЖЕРЕЛ}

1. Bartolomé, L. I. (1994). Beyond the methods fetish: Toward a humanizing pedagogy. Harvard Educational Review, 64 (2), P. 173-194

2. Bell, L., \& Schniedewind, N. (1989). Realizing the promise of humanistic education: A reconstructed pedagogy for personal and social change. Journal of Humanistic Psychology, 29, P. 200-223

3. Cammarota, J., \& Romero, A. (2006). A critically compassionate intellectualism for Latina/o students: Raising voices above the silencing in our schools. Multicultural Education, 14 (2), P. 16-23

4. Freire, P. (1970). Pedagogy of the oppressed. New York, NY: Continuum.

5. Freire, P. (1985). The politics of education: Culture, power and liberation. New York, NY: Bergin \& Garvey.

6. Frymer, B. (2005). Freire, alienation, and contemporary youth: Toward a pedagogy of everyday life. Inter Actions: UCLA Journal of Education and Information Studies, 1. Retrieved from: https://escholarship.org/uc/item/5wd2w4gs

7. Jennings, L. B., \& Da Matta, G. B. (2009). Rooted in resistance: Women teachers constructing counter-pedagogies in post-authoritarian Brazil. Teaching Education, 20, P. 215-228

8. Law, Lindsay Paige. (2015) «Humanizing education: teacher leaders influencing pedagogical change». Graduate Theses and Dissertations. 14361. Iowa State University.

9. Price, J. N., \& Osborne, M. D. (2000). Challenges of forging a humanizing pedagogy in teacher education. Curriculum and Teaching, 15 (1), P. $27-51$

10. Roberts, P. (2000). Education, literacy, and humanization: Exploring the work of Paulo Freire. Westport, CT: Bergin \& Garvey. Roberts, 2000. P. 13-14

11. Salazar, Maria del Carmen (2013). A humanizing Pedagogy. Reinventing the principles and practice of education as a journey toward liberation. 37(1), P. 121-148

\section{REFERENCES}

1. Bartolomé, L. I. (1994). Poza metodamy fetyshu: Na shliakhu do humanizatsii pedahohiky. [Beyond the methods fetish: Toward a humanizing pedagogy]. Harvard Educational Review.

2. Bell, L., \& Schniedewind, N. (1989). Realizatsiia obitsianky humanistychnoi osvity: rekonstruiovana pedahohika osobystykh $i$ sotsialnykh zmin. [Realizing the promise of humanistic education: A reconstructed pedagogy for personal and social change].

3. Cammarota, J., \& Romero, A. (2006). Krytychno spivchutlyvyi intelektualizm dlia latynoamerykanskykh studentiv: pidniattia holosiv vyshche zamovchuvannia $v$ nashykh shkolakh. [A 
critically compassionate intellectualism for Latina/o students: Raising voices above the silencing in our schools].

4. Freire, P. (1970). Pedahohika pryhnoblenykh. [Pedagogy of the oppressed]. New York.

5. Freire, P. (1985). Polityka osvity: kultura, vlada ta vyzvolennia. [The politics of education: Culture, power and liberation]. New York.

6. Frymer, B. (2005). Freir, vidchuzhennia ta suchasna molod: Na shliakhu do pedahohiky povsiakdennoho zhyttia. [Freire, alienation, and contemporary youth: Toward a pedagogy of everyday life].

7. Jennings, L. B., \& Da Matta, G. B. (2009). Korinnia oporu: zhinky-vykladachi, shcho buduiut kontrpedahohiku v postavtorytarnii Brazylii. [Rooted in resistance: Women teachers constructing counterpedagogies in post-authoritarian Brazil].

8. Law, Lindsay Paige. (2015) «Humanizuiucha osvita: kerivnyky vchyteliv, shcho vplyvaiut na pedahohichni zminy». [«Humanizing education: teacher leaders influencing pedagogical change»].

9. Price, J. N., \& Osborne, M. D. (2000). Problemy formuvannia humanizuiuchoi pedahohiky $v$ osviti vchyteliv. [Challenges of forging a humanizing pedagogy in teacher education].

10. Roberts, P. (2000). Osvita, hramotnist' ta humanizatsiya: vyvchennya roboty Paulu Freyra. [Education, literacy, and humanization: Exploring the work of Paulo Freire]. Westport.
11. Salazar, Maria del Carmen (2013). Humanizuiucha pedahohika. Vidkryttia pryntsypiv $i$ praktyky navchannia yak podorozhi do vyzvolennia. [A humanizing Pedagogy. Reinventing the principles and practice of education as a journey toward liberation].

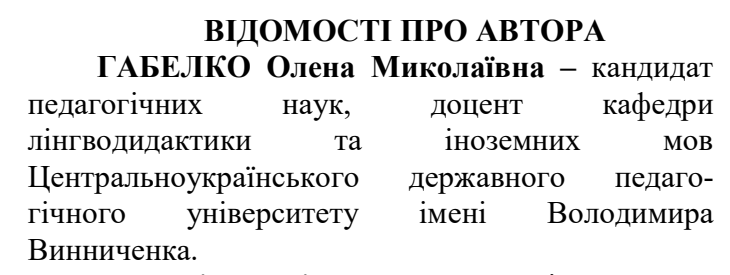

Наукові інтереси: міжкультурна комунікація, професійна педагогіка, компаративна педагогіка.

\section{INFORMATION ABOUT THE AUTHOR}

HABELKO Olena Mykolayivna - Candidate of Pedagogical Sciences, Associate Professor of the Department of Linguodidactics and Foreign Languages, Volodymyr Vynnychenko Central Ukrainian State Pedagogical University.

Circle of scientific interests: intercultural communication, professional pedagogy.

Стаття надійшла до редакиії 17.01.2020 p.

кандидат педагогічних наук, доцент, доцент кафедри дошкільної освіти Полтавського національного педагогічного університету імені В. Г. Короленка, ORCID:https://orcid.org/0000-0002-9149-3992 e-mail: missoliva20@gmail.com

КЛЕВАКА Леся Петрівна кандидат педагогічних наук, доцент кафедри психології та педагогіки Національного університету «Полтавська політехніка імені Юрія Кондратюка» ORCID:https://orcid.org/0000-0001-6924-8221 e-mail: klevakaalesi@ukr.net

\section{ВРАХУВАННЯ ІНДИВІДУАЛЬНИХ ОСОБЛИВОСТЕЙ ДІТЕЙ ДОШКІЛЬНОГО ВІКУ З РІЗНИМИ ТИПАМИ НЕРВОВОЇ СИСТЕМИ У ПРОЦЕСІ НАВЧАННЯ, ВИХОВАННЯ ТА РОЗВИТКУ}

\begin{abstract}
Постановка та обгрунтування актуальності проблеми. В останній час на рівні філософії освіти актуалізується думка про необхідність врахування в освітніх системах неповторності кожного індивіда. Можна говорити про тенденції до відмовлення від уніфікації особистості у сфері освіти. Неможливість виховання i навчання творчої людини на загальному «освітньому конвеєрі» все більш усвідомлюється педагогікою i примушує
\end{abstract}

шукати нові освітні моделі, які відповідають даній задачі. У центрі розробок нового змісту освіти і методик навчання повинна стояти дитина 3 iї власними, індивідуальними можливостями, бажаннями, потребами та інтересами. Ми звертаємося саме до дошкільної освіти, оскільки на сучасному етапі розвитку системи дошкільного виховання найбільшої гостроти набула потреба пошуку нових форм виховання i навчання, які сприяють формуванню 